University of Nebraska - Lincoln

DigitalCommons@University of Nebraska - Lincoln

1987

\title{
Stable isotope compositions of fossil mollusks from southern California: Evidence for a cool last interglacial ocean
}

Daniel R. Muhs

U.S. Geological Survey, dmuhs@usgs.gov

T. Kurtis Kyser

University of Saskatchewan

Follow this and additional works at: https://digitalcommons.unl.edu/usgsstaffpub

Part of the Earth Sciences Commons

Muhs, Daniel R. and Kyser, T. Kurtis, "Stable isotope compositions of fossil mollusks from southern California: Evidence for a cool last interglacial ocean" (1987). USGS Staff -- Published Research. 153. https://digitalcommons.unl.edu/usgsstaffpub/153

This Article is brought to you for free and open access by the US Geological Survey at DigitalCommons@University of Nebraska - Lincoln. It has been accepted for inclusion in USGS Staff -- Published Research by an authorized administrator of DigitalCommons@University of Nebraska - Lincoln. 


\title{
Stable isotope compositions of fossil mollusks from southern California: Evidence for a cool last interglacial ocean
}

\author{
Daniel R. Muhs U.S. Geological Survey, MS 424, Denver, Colorado 80225 \\ T. Kurtis Kyser Department of Geological Sciences, University of Saskatchewan \\ Saskatoon, Saskatchewan S7N OWO, Canada
}

\begin{abstract}
Stable isotope compositions have been determined for modern mullusks and fossil mollusks collected from uplifted marine terraces at three localities in southern California. By using a paleoclimatic model that decouples the temperature and ice-volume signals in ocean water, ocean-water temperatures off southern California are estimated to have been $-3.8^{\circ} \mathrm{C}$ at $\sim 85$ $\mathrm{ka},-3.0^{\circ} \mathrm{C}$ at $\sim 107 \mathrm{ka}$, and $-2.2^{\circ} \mathrm{C}$ at $\sim 125 \mathrm{ka}$ relative to present temperature. These results indicate rather cool conditions during the peak of the last interglacial stage at $125 \mathrm{ka}$ and conflict with results from terrace faunal studies that suggest water temperatures were warm or warmer than at present.
\end{abstract}

\section{INTRODUCTION}

The temperature of the ocean during the peak of the last interglacial stage at $\sim 125 \mathrm{ka}$ (oxygenisotope substage $5 \mathrm{e}$ ) has been estimated by using biotic census counts and stable isotope analyses in foraminifera from deep-sea cores (CLIMAP Project Members, 1984) and stable isotope analyses of mollusks and corals from uplifted coral-reef terraces (Shackleton and Matthews, 1977; Fairbanks and Matthews, 1978; Aharon et al., 1980; Aharon, 1983; Matthews, 1985). A general conclusion from these studies is that the temperature of the last interglacial ocean at $\sim 125 \mathrm{ka}$ was similar to the temperature of the present ocean. However, studies of deep-sea cores and terrace fossils in areas such as the Caribbean-Gulf of Mexico area, the southeastern Pacific Ocean, and around New Guinea indicate cooler-than-present temperatures for the last interglacial ocean (CLIMAP Project Members, 1984; Aharon et al., 1980). Data are sparse from the northeastern Pacific Ocean basin because sedimentation rates are high. With one exception off the coast of Oregon (Heusser and Shackleton, 1979), none of the many cores from this area intersect the boundary between the last interglacial stage and the beginning of the Wisconsin Glaciation (e.g., Gorsline and Prensky, 1975; Kahn et al., 1981). The marine paleoclimate of the ocean off the west coast of North America during the last interglacial stage has been inferred from the geographic ranges of fossils from tectonically uplifted marine terraces (Grant and Gale, 1931; Woodring et al., 1946; Valentine, 1955, 1961; Emerson, 1956; Valentine and Meade, 1961; Addicott, 1966; Zinsmeister, 1974; Valentine, 1976; Kern, 1977; Kennedy, 1978; Emerson et al., 1981; Kennedy et al., 1982; Kennedy and Wehmiller, 1986). Such interpretations have often been compli- cated by fossil assemblages that have a mixture of both warm and cool faunas. Most of these complications have disappeared with better age control (Kennedy, 1982), but several wellmapped and confidently dated 125-ka terraces do indeed have both warm and cool faunal elements. Examples include the Palos Verdes Sand Cabrillo Beach terrace in San Pedro (Woodring et al., 1946; Valentine and Meade, 1961; Muhs and Rosholt, 1984); the second terrace on San Nicolas Island (Vedder and Norris,
1963; Valentine and Veeh, 1969); the Nestor terrace in San Diego (Ku and Kern, 1974; Kern, 1977); and the second terrace at Turtle Bay, Baja California (Emerson et al., 1981).

Oxygen-isotope studies of Quaternary marine mollusks have been used only occasionally for paleoclimatic studies in California, despite the widespread abundance of fossils in marine terraces (Valentine and Meade, 1961; Dodd, 1966; Killingley, 1983). Marine-terrace fossils are, however, attractive for stable isotope studies because (1) terrace fossils are abundant in California, (2) marine terraces can now be dated by several methods, and (3) unlike deep-sea cores, the ice-volume signal in stable isotope data can be decoupled from the paleoclimatic signal by using well-established sea-level curves (Aharon et al., 1980; Aharon, 1983). We sampled fossil bivalve mollusks from marine terraces on San Clemente Island, San Nicolas Island, and at Point Loma in San Diego, California (Fig. 1), as

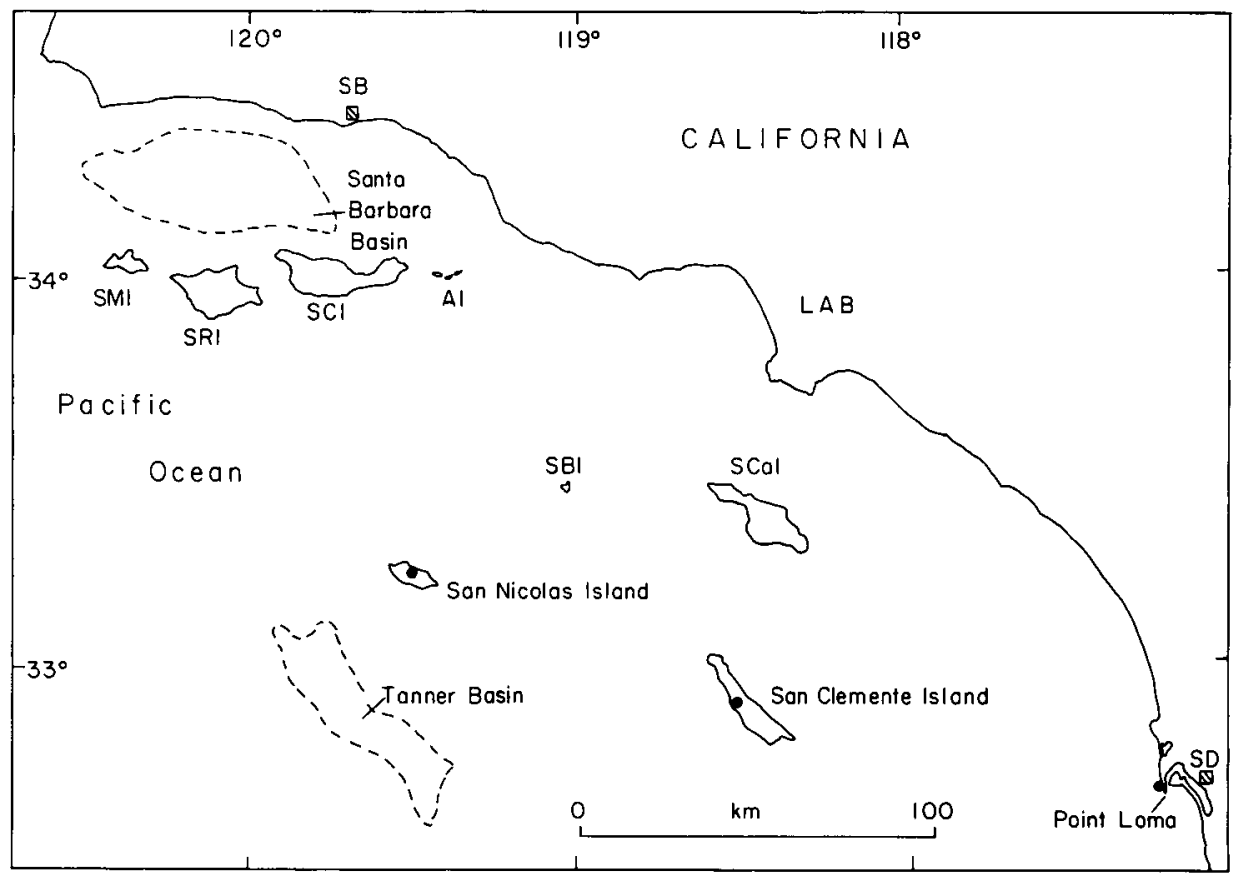

Figure 1. Map showing localities studied. LAB = Los Angeles basin; SB = Santa Barbara; SD = San Dlego; SMI = San Miguel Island; SRI = Santa Rosa Island; SCI = Santa Cruz Island; AI = Anacapa Islands; SCaI = Santa Catallna Island. Large dots indicate sample localities. 
well as modern shells from nearby marine habitats. At all three localities there are 125-ka terraces (deep-sea substage $5 \mathrm{e}$ ) that have been dated by uranium-series methods on coral (Valentine and Veeh, 1969; Ku and Kern, 1974; Muhs and Szabo, 1982). The lower, younger terraces on San Clemente Island and San Nicholas Island have amino-acid age estimates of about $85 \mathrm{ka}$ (deep-sea substage 5a) and $107 \mathrm{ka}$ (deep-sea substage 5c), respectively (Muhs, 1983,1985 ). Our goal was to determine ocean paleotemperatures from the oxygen-isotope composition of the fossils.

\section{METHODS}

The small bivalve Epilucina californica was analyzed in this study because it is the only fossil that is found in abundance at all three localities. All samples were first examined under a binocular microscope for evidence of algal borings, and the contaminated areas were removed. Previous studies of marine mollusks clearly show that oxygen-isotope values vary in relation to seasonal temperature changes when individual layers are analyzed (Killingley and Berger, 1979; Killingley, 1981, 1983; Jones et al., 1986). Therefore, radial sections cut parallel to the direction of growth or the entire individual was analyzed so that an integrated thermal history would be represented. All samples were ground to a fine powder and were $99 \%-100 \%$ aragonite as determined by $\mathrm{X}$-ray diffraction analysis. Isotopic compositions were determined by using the $\mathrm{H}_{3} \mathrm{PO}_{4}$ method of McCrea (1950) and are reported in $\delta$ notation in units of per mil relative to PDB. By using this method, a $\delta^{13} \mathrm{C}$ value of $-5.00 \%$ and a $\delta^{18} \mathrm{O}$ value of $+7.20 \%$ were measured for NBS-19. No significant isotopic differences were detected between untreated splits of samples and those that were either treated with sodium hypochlorite or hieated to remove organic material. Duplicate analyses indicate a $1 \sigma$ reproducibility of \pm 0.04 for both carbon and oxygen.

\section{ISOTOPIC COMPOSITION OF MODERN MOLLUSKS}

The $\delta^{18} \mathrm{O}$ values of the modern spizcimens indicate that biological fractionation effects in Epilucina are minimal and that this speries is a reliable indicator of temperature (Table 1). Modern mean annual sea-surface (10-m depth) temperatures are about $16^{\circ} \mathrm{C}$ at both San Diego and San Clemente Island (Lynn, 196i5), and modern Epilucina specimens from these two localities have $\delta^{18} \mathrm{O}$ values that are not significantly different from one another. In contrast, the sea-surface temperature near San Nicolas Island is $\sim 15^{\circ} \mathrm{C}$, and the $\delta^{18} \mathrm{O}$ values of shells from that locality are significantly higher than values in shells from San Diego (at the 95\% confidence level) and San Clemente Isliand (at the $99 \%$ confidence level). On the assumption that a $1{ }^{\circ} \mathrm{C}$ temperature difference is equivalent to a $\delta^{18} \mathrm{O}$ difference of about $0.23 \%$ (IEpstein et al., 1953), the difference in water temperature between San Nicolas Island and the other two localities is about $1.3^{\circ} \mathrm{C}$ on the basis of oxygenisotope data, which agrees well with th: measured temperature difference.

\section{ISOTOPIC COMPOSITION OF FOSSIL MOLLUSKS}

Analyses of fossil Epilucina indicate thet there are significant differences between the stalsle isotope compositions of fossils having differe at ages (Table 1). On San Nicolas Island, samples from the $\sim 107-\mathrm{ka}$ terrace have $\delta^{18} \mathrm{O}$ values :ignificantly higher (at the $98 \%$ confidence level) than those from the 125-ka terrace; a similar differ- ence is seen between the single sample from the 85-ka terrace on San Clemente Island and samples from the corresponding 125-ka terrace. These data support the observation of Kern (1977), Kennedy (1978), and Kennedy et al. (1982) that faunas from 85-107-ka terraces in California indicate cooler water conditions than those at $\sim 12.5 \mathrm{ka}$. Thus, oxygen-isotope data may be useful in relative-age differentiation and correlation of late Pleistocene marine-terrace deposits in California.

The $\delta^{18} \mathrm{O}$ values of the 125 -ka fossils are significantly higher than those of the modern specimens (Table 1). T-tests indicate that these differences are significant at confidence levels of 95\% (San Diego), 99\% (San Clemente Island), and $99.9 \%$ (San Nicolas Island). Because shoreline and radiometric data from tectonically stable coastlines indicate that sea level at $\sim 125 \mathrm{ka}$ was 2-10 $\mathrm{m}$ higher than at present (Veeh, 1966; Ku et al., 1974), oceanic waters at that time should have had a slightly lower $\delta^{18} \mathrm{O}$ value than those of the modern ocean due to the icevolume effect, even if there were no oceanic temperature differences. Thus, our data indicate that, relative to present conditions, temperatures off the California coast during the peak of the last interglacial stage were significantly cooler.

\section{PALEOTEMPERATURE ESTIMATES}

Paleotemperatures can be generated from the oxygen-isotope data for the $85 \mathrm{ka}, 107 \mathrm{ka}$, and 125 ka highstands of sea, after accounting for the ice-volume effects, by following the method of Aharon et al. (1980). In brief, the first step is to assume that all of the observed differences between fossil and present $\delta^{18} \mathrm{O}$ values are due to ice-volume effects, and an ancient sea level is calculated (Table 1). In making this calculation, we have assumed a $0.11 \%$ change in $\delta^{18} \mathrm{O}$

Table 1. STABLE ISOTOPE DATA, MODERN SEA SURFACE TEMPERATIJES, SEA LEVELS, AND AGES FOR SOUTHERN CALIFORNIA MARINE TER'ZACES

\begin{tabular}{|c|c|c|c|c|c|c|c|c|c|c|c|}
\hline Locality & $\begin{array}{l}\text { Present } \\
\text { temp.* } \\
\left({ }^{\circ} \mathrm{C}\right)\end{array}$ & Terrace & $\begin{array}{l}\text { Ages }^{\dagger} \\
\text { (ka) }\end{array}$ & $\begin{array}{l}\text { Present }{ }^{\dagger} \\
\text { elevation } \\
\text { (m) }\end{array}$ & $\begin{array}{c}\text { Est Imated } \\
\text { sea } \\
\text { level } \\
(\mathrm{m})\end{array}$ & $\begin{array}{c}\text { No. of } \\
\text { individuals** }\end{array}$ & $\begin{array}{l}\delta^{13} \mathrm{C} \\
(\mathrm{PDB})\end{array}$ & $\begin{array}{l}\delta^{18} 0 \\
(\mathrm{PDB})\end{array}$ & $\begin{array}{c}a^{180} 0 \\
\text { sea level } \\
(m)\end{array}$ & $\begin{array}{c}\delta^{100} \\
\text { residual } \\
(\% 0)\end{array}$ & $\begin{array}{l}\Delta \mathrm{T}^{\S 5} \\
\left({ }^{\circ} \mathrm{C}\right)\end{array}$ \\
\hline $\begin{array}{l}\text { San } \\
\text { Clemente } \\
\text { Island }\end{array}$ & -16.0 & $\begin{array}{l}\text { Modern } \\
\text { 1st } \\
\text { 2nd }\end{array}$ & $\begin{array}{c}0 \\
-85 \\
127 \quad 17\end{array}$ & $\begin{array}{r}0 \\
5 \\
32\end{array}$ & $\begin{array}{r}0 \\
-13 \\
+6\end{array}$ & $\begin{array}{ll}6 & (11) \\
1 & (2) \\
4 & (8)\end{array}$ & $\begin{array}{r}1.96 \pm 0.39 \\
-2.14 \\
2.14 \pm 0.15\end{array}$ & $\begin{array}{r}0.26 \pm 0.17 \\
-1.27 \\
0.69 \pm 0.12\end{array}$ & $\begin{array}{l}-- \\
-92 \\
-39\end{array}$ & $\begin{array}{l}0.87 \\
0.87 \\
0.50\end{array}$ & $\begin{array}{l}-- \\
-3.8 \\
-2.2\end{array}$ \\
\hline $\begin{array}{l}\text { San } \\
\text { Nicolas } \\
\text { Island }\end{array}$ & -15.0 & $\begin{array}{l}\text { Modern } \\
1 \mathrm{st} \\
\text { 2nd }\end{array}$ & $\begin{array}{r}0 \\
-107 \\
120 \pm 20\end{array}$ & $\begin{array}{r}0 \\
11 \\
31\end{array}$ & $\begin{array}{r}0 \\
-10 \\
+6\end{array}$ & $\begin{array}{ll}7 & (20) \\
6 & (14) \\
4 & (8)\end{array}$ & $\begin{array}{l}2.45 \pm 0.35 \\
1.61 \pm 0.28 \\
1.65 \pm 0.43\end{array}$ & $\begin{array}{l}0.61 \pm 0.12 \\
1.42 \pm 0.15 \\
1.05 \pm 0.14\end{array}$ & $\begin{array}{l}-- \\
-74 \\
-40\end{array}$ & $\begin{array}{l}-- \\
0.70 \\
0.51\end{array}$ & $\begin{array}{l}-- \\
-3.0 \\
-2.2\end{array}$ \\
\hline $\begin{array}{l}\text { San Diego } \\
\text { (Point Loma) }\end{array}$ & -16.0 & $\begin{array}{l}\text { Modern } \\
\text { Nestor }\end{array}$ & $\begin{array}{c}0 \\
121 \pm 10\end{array}$ & $\begin{array}{r}0 \\
25\end{array}$ & $\begin{array}{r}0 \\
+6\end{array}$ & $\begin{array}{l}3(8) \\
3(9)\end{array}$ & $\begin{array}{l}1.29 \pm 0.64 \\
2.09 \pm 0.25\end{array}$ & $\begin{array}{l}0.34 \pm 0.16 \\
0.82 \pm 0.14\end{array}$ & -44 & $\overline{0.55}$ & $\begin{array}{l}-- \\
-2.4\end{array}$ \\
\hline \multicolumn{12}{|c|}{ 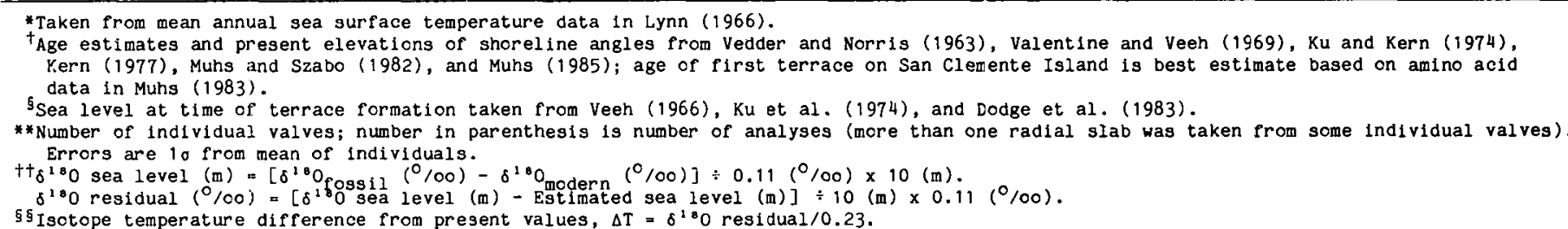 } \\
\hline
\end{tabular}


between modern and fossil shells for each 10-m change in sea level (Shackleton and Opdyke, 1973; Fairbanks and Matthews, 1978; Aharon et al., 1980; Dodge et al., 1983). This calculated sea level is then compared to the sea level determined independently from terrace elevation data (Mesolella et al., 1969; Bloom et al., 1974; Dodge et al., 1983; Chappell, 1983), and a "residual" $\delta^{18} \mathrm{O}$ value is determined. This latter value represents the difference in the $\delta^{18} \mathrm{O}$ values between fossil and modern specimens that is due to temperature.

Our calculations indicate that ocean surface temperatures off California were cooler at 85 and $107 \mathrm{ka}$ than at present (Table 1). The temperature estimate at $85 \mathrm{ka}$ is tentative because we had only one individual of this age for analysis from San Clemente Island. Even though the 85 and $107 \mathrm{ka}$ highstands are sometimes considered to be "interglacial," our data suggest that they were accompanied by rather cool water temperatures on the California coast. Studies of stable isotope compositions of foraminifera derived from a core taken from nearby Tanner Basin (Fig. 1) indicate that the difference in temperature between the last glacial maximum and the Holocene thermal maximum was about $5^{\circ} \mathrm{C}$ (Kahn et al., 1981). Thus, our data indicate that the amount of cooling (relative to the present) at 85 and $107 \mathrm{ka}$ along the California coast was more than half the amount of cooling during the glacial maximum. In contrast, stable isotope data from reef terraces in New Guinea and Barbados indicate that at both 85 and $107 \mathrm{ka}$, there was virtually no change in tropical surface-water temperatures compared to the present (Aharon et al., 1980; Aharon, 1983; Matthews, 1985).

Calculations of temperature changes from $125 \mathrm{ka}$ to the present are in agreement at all three of our localities and indicate that water temperatures off southern California were 2.2-2.4 ${ }^{\circ} \mathrm{C}$ cooler during the peak of the last interglacial stage than at present (Table 1). These results are contrary to those from most other areas studied by CLIMAP Project Members (1984), which indicated that the temperature of the last interglacial ocean was virtually the same as that of the present ocean. The results are also contrary to conclusions of faunal studies, which generally indicate that coastal California water temperatures were as warm or warmer at $\sim 125 \mathrm{ka}$ than at present (Valentine, 1961; Kern, 1977; Kennedy et al., 1982; Kennedy and Wehmiller, 1986). It should be noted, however, that the CLIMAP study showed that some parts of the global ocean, such as areas in the western equatorial Atlantic-Caribbean-Gulf of Mexico area and the southeastern Pacific off western South America, were significantly cooler at $\sim 125 \mathrm{ka}$ than at present. In addition, other studies in southern California indicate that the last interglacial period at $125 \mathrm{ka}$ was not uniformly warmer than at present. We have already mentioned that several 125 ka terraces in southern California have mixtures of warm and cool faunal elements, although the warm elements are usually dominant. A previous stable isotope study of mollusks from the Nestor terrace on Point Loma, California, indicated that mean annual surface-water temperatures at $125 \mathrm{ka}$ were $0.8-3.6^{\circ} \mathrm{C}$ cooler than at present $\left(\sim 16.0^{\circ} \mathrm{C}\right)$ (Valentine and Meade, 1961). There is also evidence that there has been considerable temperature variability off southern California within the Holocene. Studies of radiolarian faunas from a varved sediment core in the Santa Barbara Basin (Fig. 1) indicate that mean February sea-surface temperatures during the Holocene may have varied from about 11 to $25^{\circ} \mathrm{C}$ (Pisias, 1978). In a Tanner Basin (Fig. 1) core, Holocene mean annual surface-water paleotemperatures as much as $4.5^{\circ} \mathrm{C}$ lower than at present have been estimated (Kahn et al., 1981). These studies all suggest that generalizations about "warm" interglacial water temperatures and "cool" glacial or interstadial water temperatures off the California coast are no doubt oversimplified.

\section{PALEOCEANOGRAPHY}

Cooler-than-present temperatures off the California coast during the peak of the last interglacial stage at $\sim 125 \mathrm{ka}$ could have resulted from two different mechanisms related to the California Current. The California Current is accompanied by upwelling of cooler bottom waters at many places along the southern California coast. An increase in the strength of northerly winds increases both the strength of the current and the amount of upwelling (Pisias, 1978). Studies of modern mollusks have shown that individual growth layers quite faithfully record lower $\delta^{13} \mathrm{C}$ values during the southern California spring upwelling season (Killingley and Berger, 1979). Our data indicate that increased upwelling at 107 and $125 \mathrm{ka}$ may have been a factor on San Nicolas Island, as $\delta^{13} \mathrm{C}$ values in shells from the 107 and $125 \mathrm{ka}$ terraces are significantly lower than those in the modern shells, at the $98 \%$ confidence level (Table 1). For San Diego and San Clemente Island, however, t-tests showed no significant differences between the $\delta^{13} \mathrm{C}$ values of modern and 85 or $125 \mathrm{ka}$ shells, which does not support the existence of stronger upwelling in the past.

A second mechanism that may have resulted in cooler temperatures during the peak of the last interglacial stage is a greater contribution of high-latitude source waters to the California Current at that time than at present. The modern California Current is a continuation of the Aleutian or Subarctic Current, which in turn forms by mixing of the Kuroshio and Oyashio currents (Sverdrup et al., 1942). Little mixing of the southward-flowing California Current with the
North Pacific Current to the west takes place, as evidenced by the relatively cool temperatures of the California Current and $\delta^{18} \mathrm{O}$ surface-water values, which are similar to those of Pacific Ocean surface waters at much higher latitudes (Broecker, 1986). If, during the peak of the last interglacial period, the Oyashio Current contributed more cold water to the Subarctic Current than it does at present, the result would be a cooler California Current that may or may not have been accompanied by increased upwelling, depending on local wind strengths. In this model, cooler-than-present ocean temperatures should be recorded in 125-ka marine fossils all along the Pacific coast of North America affected by the California Current. However, foraminiferal data from a single core off the coast of southern Oregon and marine-terrace faunas from a locality in central Oregon indicate that water temperatures at $125 \mathrm{ka}$ were slightly warmer than at present (CLIMAP Project Members, 1984; Kennedy, 1978; Kennedy et al., 1982). To test this model more rigorously, however, oxygen-isotope compositions of mollusks are needed from well-dated $125 \mathrm{ka}$ marine terraces and their modern equivalents along the Pacific coast of North America from about lat $50^{\circ}$ to $25^{\circ} \mathrm{N}$.

The cooler-than-present water temperatures off southern California at $\sim 85$ and $\sim 107 \mathrm{ka}$ are in agreement with faunal data of Kern (1977), Kennedy (1978), Kennedy et al. (1982), and Kennedy and Wehmiller (1986), but they cannot be explained by increased upwelling, at least on San Clemente Island. Clearly, data from mollusks of these ages are needed from more localities, but cooler waters at these times may be explained by cooler Pacific Ocean deep water during the time interval from $\sim 115$ to $\sim 10 \mathrm{ka}$ (Shackleton and Chappell, 1985).

\section{CONCLUSIONS}

Stable isotope studies of modern and fossil mollusks indicate that during the last interglacial stage, water temperatures off the southern California coast were cooler than at present. These temperature reductions are estimated to be -3.8 ${ }^{\circ} \mathrm{C}$ at $\sim 85 \mathrm{ka},-3.0^{\circ} \mathrm{C}$ at $\sim 107 \mathrm{ka}$, and $-2.2^{\circ} \mathrm{C}$ at $\sim 125 \mathrm{ka}$. The cooler-than-present waters at $\sim 85$ and $\sim 107 \mathrm{ka}$ are in agreement with faunal data and may be explained by deep-water cooling in the Pacific Ocean in the time interval from $\sim 115$ to $\sim 10 \mathrm{ka}$. However, neither this mechanism nor upwelling explain the coolerthan-present waters at $\sim 125 \mathrm{ka}$ indicated by the stable isotope data. Faunas from 125-ka terraces in southern California have both warm and cool species at several localities, although warmwater forms seem to be dominant.

More studies are needed before we can adequately explain the anomalous data that suggest cool-water conditions existed off the California coast during the peak of the last interglacial 
stage at $125 \mathrm{ka}$. Our results do indicate, however, that oceanic paleotemperatures in this region are not a simple case of warm interglacial vs. cool glacial or interstadial periods and that the mechanisms of climatic change in this area are probably more complex than previously supposed.

\section{REFERENCES CITED}

Addicott, W.O., 1966, Late Pleistocene marine paleoecology and zoogeography in central California: U.S. Geological Survey Professional Paper 523-C, 21 p.

Aharon, P., 1983, 140,000-yr isotope climatic record from raised coral reefs in New Guinea: Nature, v. 304 , p. $720-723$.

Aharon, P., Chappell, J., and Compston, W., 1980, Stable isotope and sea-level data from New Guinea supports Antarctic ice-surge theory of ice ages: Nature, v. 283 , p. 649-651.

Bloom, A.L., Broecker, W.S., Chappell, J.M.A., Matthews, R.K., and Mesolella, K.J., 1974, Quaternary sea-level fluctuations on a tectonic coast: New ${ }^{230} \mathrm{Th} /{ }^{234} \mathrm{U}$ dates from the Huon Peninsula, New Guinea: Quaternary Research, v. 4 p. 185-205.

Broecker, W.S., 1986, Oxygen isotope constraints on surface ocean temperatures: Quaternary Research, v. 26, p. 121-134.

Chappell, J., 1983, A revised sea-level record for the last 300,000 years from Papua New Guinea: Search, v. 14, p. 99-101.

CLIMAP Project Members, 1984, The last interglacial ocean: Quaternary Research, v. 21, p. 123-224.

Dodd, J.R., 1966, Diagenetic stability of temperaturesensitive skeletal properties in Mytilus from the Pleistocene of California: Geological Society of America Bulletin, v. 77, p. 1213-1224.

Dodge, R.E., Fairbanks, R.G., Benninger, L.K. and Maurrasse, F., 1983, Pleistocene sea levels from raised coral reefs of Haiti: Science, v. 219. p. $1423-1425$.

Emerson, W.K., 1956, Pleistocene invertebrates from Punta China, Baja California, Mexico: American Museum of Natural History Bulletin, v. 3, art. 4, p. 319-342.

Emerson, W.K., Kennedy, G.L., Wehmiller, J.F., and Keenan, E., 1981, Age relations and zoogeographic implications of late Pleistocene marine invertebrate faunas from Turtle Bay, Baja California Sur, Mexico: Nautilus, v. 95, p. $105-116$.

Epstein, S., Buchsbaum, R., Lowenstam, H.A., and Urey, H.C., 1953, Revised carbonate-water isotopic temperature scale: Geological Society of America Bulletin, v. 64, p. 1315-1326.

Fairbanks, R.G., and Matthews, R.K., 1978, The marine oxygen isotope record in Pleistocene coral, Barbados, West Indies: Quaternary Research, v. 10, p. 181-196.

Gorsline, D.S., and Prensky, S.E., 1975, Paleoclimatic inferences for late Pleistocene and Holocene from California Continental Borderland basin sediments, in Suggate, R.P., and Cressell, M.M., eds., Quaternary studies: Wellington, Royal Society of New Zealand, p. 147-154

Grant, U.S., IV, and Gale, H.R., 1931, Catalogue of the marine Pliocene and Pleistocene Mollusca of California and adjacent regions: San Diego Society of Natural History Memoir 1, 1036 p.

Heusser, L.E., and Shackleton, N.J., 1979, Direct marine-continental correlation: 150,000 -year oxygen isotope-pollen record from the North Pacific: Science, v. 204, p. 837-839.
Jones, D.S., Williams, D.F., and Romanek, C.S., 1986, Life history of symbiont-bearing giant clams from stable isotope profiles: Science, v. 231 , p. $46-48$.

Kahn, M.I., Oba, T., and Ku, T.-L., 1981, Paleotemperatures and the glacially induced changes in the oxygen-isotope composition of sea waler during late Pleistocene and Holocene time in 'Tanner Basin, California: Geology, v. 9, p. 485-4'70.

Kennedy, G.L., 1978, Pleistocene paleoecology, zoogeography and geochronology of marine invertebrate faunas of the Pacific Northwest coast (San Francisco Bay to Puget Sound) [Ph.D. thesis] Davis, University of California, 824 p.

- 1982, Historical evolution and application of the Pleistocene province concept along the eastern Pacific margin of North America: Western Society of Malacologists Annual Report, v. 14, p. 14-15.

Kennedy, G.L., and Wehmiller, J.F., 1986, Paleoclimatic implications of Quaternary marine invertebrate faunas from southwestern Santa Barbara County, California: Western Soziety of Malacologists Annual Report, v. 18, p. 2!'-23.

Kennedy, G.L., Lajoie, K.R., and Wehmiller, J.F., 1982, Aminostratigraphy and faunal correlations of late Quaternary marine terraces, Pacifi: Coast, USA: Nature, v. 299, p. 545-547.

Kern, J.P., 1977, Origin and history of upper Pleistocene marine terraces, San Diego, Californ a: Geological Society of America Bulletin, v. 88, p. 1553-1566.

Killingley, J.S., 1981, Seasonality of mollusk collecting determined from $0-18$ profiles of midden shells: American Antiquity, v. 46, p. 152-158.

1983, Seasonality determination by oxy.zen isotopic profile: A reply to Bailey et al.: Anerican Antiquity, v. 48, p. 399-403.

Killingley, J.S., and Berger, W.H., 1979, Stable isotopes in a mollusk shell: Detection of ujwelling events: Science, v. 205, p. 186-188.

Ku, T.-L., and Kern, J.P., 1974, Uranium-serits age of the upper Pleistocene Nestor Terrare, San Diego, California: Geological Society of America Bulletin, v. 85, p. 1713-1716.

Ku, T.-L., Kimmel, M.A., Easton, W.H., and O'Neil, T.J., 1974, Eustatic sea level 120,000 y ars ago on Oahu, Hawaii: Science, v. 183, p. 95!?-962.

Lynn, R.J., 1966, Seasonal variation of temperature and salinity at 10 meters in the Califonia Current: California Cooperative Oceanic Fisheries Investigations, v. 9, p. 157-186.

Matthews, R.K., 1985, The $\delta^{18} \mathrm{O}$ signal of ieep-sea planktonic foraminifera at low latitudes $\varepsilon s$ an icevolume indicator: South African Journal of Science, v. 81, p. 274-275.

McCrea, J.M., 1950, The isotopic cherristry of carbonates and a paleotemperature scale: Journal of Chemical Physics, v. 18, p. 849-857.

Mesolella, K.J., Matthews, R.K., Broecker, V/.S., and Thurber, D.L., 1969, The astronomical theory of climatic change: Barbados data: Journal of Geology, v. 77 , p. $250-274$.

Muhs, D.R., 1983, Quaternary sea-level events on northern San Clemente Island, California: Quaternary Research, v. 20, p. 322-341.

- 1985, Amino acid age estimates of marine terraces and sea levels on San Nicolas Island, California: Geology, v. 13, p. 58-61.

Muhs, D.R., and Rosholt, J.N., 1984, Ages of marine terraces on the Palos Verdes Hills, California, by amino acid and uranium-trend dating: Geological Society of America Abstracts with Programs, v. 16, p. 603.
Muhs, D.R., and Szabo, B.J., 1982, Uranium-series age of the Eel Point terrace, San Clemente Island, California: Geology, v. 10, p. 23-26.

Pisias, N.G., 1978, Paleoceanography of the Santa Barbara Basin during the last 8,000 years: Quaternary Research, v. 10, p. 366-384.

Shackleton, N.J., and Chappell, J., 1985, The ocean deep-water oxygen isotope record and the New Guinea sea-level record: EOS (American Geophysical Union Transactions), v. 66, p. 293.

Shackleton, N.J., and Matthews, R.K., 1977, Oxygen isotope stratigraphy of late Pleistocene coral terraces in Barbados: Nature, v. 268, p. 618-620.

Shackleton, N.J., and Opdyke, N.D., 1973, Oxygen isotope and paleomagnetic stratigraphy of equatorial Pacific core V23-238: Oxygen isotope temperatures and ice volumes on a $10^{5}$ and $10^{6}$ year time scale: Quaternary Research, v. 3, p. $39-55$.

Sverdrup, H.U., Johnson, M.W., and Fleming, R.H., 1942, The cceans: Their physics, chemistry, and general biology: New York, Prentice-Hall, Inc., $1087 \mathrm{p}$.

Valentine, J.W., 1955, Upwelling and thermally anomalous Pacific coast Pleistocene molluscan faunas: American Journal of Science, v. 253, p. 462-474.

- 1961, Paleoecologic molluscan geography of the Californian Pleistocene: University of California Publications in the Geological Sciences, v. 34, p. 309-442.

Valentine, J.W., and Meade, R.F., 1961, California Pleistocene paleotemperatures: University of California Publications in the Geological Sciences, v. 40, p. 1-46.

Valentine, J.W., and Veeh, H.H., 1969, Radiometric ages of Pleistocene terraces from San Nicolas Island, California: Geological Society of America Bulletin, v. 80, p. 1415-1418.

Valentine, P.C., 1976, Zoogeography of Holocene Ostracoda off western North America and paleoclimatic implications: U.S. Geological Survey Professional Paper 916, $47 \mathrm{p}$.

Vedder, J.G., and Norris, R.J., 1963, Geology of San Nicolas Island, California: U.S. Geological Survey Professional Paper 369, 65 p.

Veeh, H.H., 1966, Th ${ }^{230} / U^{238}$ and $U^{234} / U^{238}$ ages of Pleistocene high sea level stand: Journal of Geophysical Research, v. 71, p. 3379-3386.

Woodring, W.P., Bramlette, M.N., and Kew, W.S.W., 1946, Geology and paleontology of Palos Verdes Hills, California: U.S. Geological Survey Professional Paper 207, $145 \mathrm{p}$.

Zinsmeister, W.J., 1974, A new interpretation of thermally anomalous molluscan assemblages of the California Pleistocene: Journal of Paleontology, v. 48, p. 84-94.

\section{ACKNOWLEIDGMENTS}

Supported in part by a National Research CouncilU.S. Geological Survey Research Associateship (to Muhs) and grants from the U.S. Geological Survey and the National Science and Engineering Research Council of Canada (to Kyser). We thank the U.S. Navy for access to San Nicolas Island, San Clemente Island, and Point Loma; T. R. Rowland, J. N. Rosholt, and J.P. Kern for assistance in collecting samples; and G. L. Kennedy. R. K. Matthews, J. F. Whelan, and B. J. Szabo for helpful comments on an earlier version of the paper.

Manuscript received June 24, 1986

Revised manuscript received September 24, 1986

Manuscript accepted October 24, 1986 